\title{
Efektifitas Aplikasi In-vitro Rizobakteri Sebagai Agen Antagonis Layu Fusarium pada Pisang Rajabulu/AAB di Rumah Kaca
}

\author{
The Effect of Rhizobacteria Through In vitro Application to Suppressed Fusarium Wilt on cv \\ Rajabulu/AAB Plantains in The Green House
}

\author{
Kasutjianingati $^{1}$, Roedhy Poerwanto ${ }^{2}$, Widodo $^{3}$, Nurul Khumaida ${ }^{2}$ dan Darda Efendi ${ }^{2}$ \\ Diterima 3 Desember 2010/Disetujui 10 Februari 2011
}

\begin{abstract}
Research was conducted on a banana cultivar of Rajabulu/AAB inside the green house. This research was aimed to study the effect of rhizobacteria and the ability of in vitro bacterization to prevent FOC. This study was conducted using split plot design. The main plot was rhizobacteria treatments (P. fluorescens ES-32, B. subtilis SB-3, a mix of both types and without bacteria), sub plots consist of in vitro ( 2 weeks and 1 week prior to application) and in vivo (during acclimatization) bacterization. All treatments were repeated 3 times, each consist of 7 polibags. The result of rhizobacteria treatment $(B$. subtilis SB3 or P. fluorecens ES32) was able to reduce the Disease Severity (Rhizome Discoloration) caused by Fusarium oxysporum f.sp cubense (FOC). The incorporation of mixed rhizobacteria provided significant effect suppressing the infestation of FOC. The application of mix bacteria was better than single treatment.
\end{abstract}

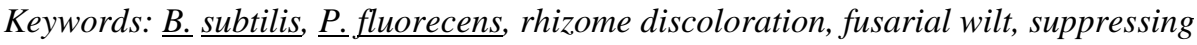

\section{PENDAHULUAN}

Kendala utama yang membatasi produksi pisang di daerah tropis adalah tingginya tingkat serangan penyakit layu Fusarium atau penyakit Panama yang disebabkan oleh Fusarium oxysporum Schlecht f.sp cubense (E.F. Smith) (FOC). Layu Fusarium juga merupakan penyebab utama kehilangan hasil yang paling penting di seluruh dunia (Wardlaw 1972, Gowen 1995, Ditlinhorti 2005). FOC sangat sulit dikendalikan dengan fungisida maupun kultur teknis, karena penyerangannya dimulai dari akar sehingga deteksi gejala sering terlambat. FOC bertahan hidup sebagai khlamidospora dalam tanah untuk kurun waktu sangat lama \pm 30 tahun (Ploetz, 1998). Sampai saat ini belum ada jenis tanaman pisang yang tahan. Informasi yang berhubungan dengan modifikasi faktor lingkungan dan pemanfaatan agens hayati masih belum memuaskan, sehingga penting untuk dikaji dan dipelajari lebih cermat.

Pengembangan perkebunan pisang di Indonesia mempunyai kendala utama dalam hal ketersediaan bibit bermutu. Mutu bibit pisang secara konvensional sangat rendah, jumlah terbatas, umur bibit tidak seragam dan adanya hambatan patogen tular tanah (soil borne). Hal tersebut dapat terjawab melalui teknik perbanyakan kultur jaringan, tetapi dilaporkan bahwa bibit hasil kultur jaringan lebih rentan terhadap layu Fusarium dibanding bibit asal anakan (Ploetz dan Pegg, 2000). Oleh karena itu perlu suatu upaya untuk meningkatkan mutu saniter planlet dengan memproteksi daerah perakaran planlet dengan agens biokontrol, sehingga mampu menjadi bahan tanam (bibit) yang aman terhadap patogen di lapangan. Penggabungan teknik perbanyakan secara kultur jaringan dengan mikro organisme pengendali hayati atau disebut kokultur, sangat tepat untuk menjawab permasalahan tersebut. Kemampuan rizobakteri berasosiasi bersama planlet pisang sejak planlet in vitro diharapkan mampu memberikan beberapa keuntungan: bakteri dapat berproliferasi di akar lebih awal, merangsang pertumbuhan dan perkembangan bibit lebih baik, transportasi bibit bermutu lebih efisien dan terpenting mampu menekan patogen di lapangan.

Beberapa rizobakteri terbukti menghasilkan sitokinin, auksin dan giberelin sehingga mampu mendukung pertumbuhan tanaman, Frommel et al. (1991) dan Nowak (1998) membuktikan bahwa bakterisasi yang dilakukan pada eksplan kentang sejak fase in vitro mampu meningkatkan bobot basah dan akar pertanaman fase bibit,

\footnotetext{
${ }^{1}$ Departemen Produksi Pertanian, Politeknik Negeri Jember, J1 Mastrip PoBox 164. Jember,Email:kasutjianingati@yahoo.com

${ }^{2}$ Departemen Agronomi dan Hortikultura, Fakultas Pertanian, IPB,

Jl Meranti, Kampus Darmaga Bogor

${ }^{3}$ Departemen Hama dan Penyakit, Fakultas Pertanian, IPB,

J1. Kamper, Kampus Darmaga Bogor
} 
vigor lebih kokoh. Barka et al. (2002) melakukan hal yang sama pada planlet anggur dan terbukti tanaman yang dihasilkan mampu menekan patogen. Kasutjianingati (2010) melakukan bakterisasi in vitro pada eksplan pisang Rajabulu stadia planlet dengan rizobakteri (P. fluorescens ES-32, B. subtilis SB-3) dan terbukti mampu mendorong multiplikasi tunas pada media MS0, meskipun hasil tunas lebih rendah bila dibandingkan dengan eksplan yang ditumbuhkan pada media yang mengandung sitokinin dan auksin. Belum dibuktikan apakah planlet terbakterisasi in vitro tersebut mampu bertahan terhadap FOC. Mekanisme pengendalian agens hayati terhadap patogen yang menginfeksi tanaman dapat terjadi secara langsung maupun tidak langsung. Pengendalian secara langsung menurut Zhang (2004), dapat terjadi melalui mekanisme antibiosis, kompetisi, parasitisme dan lisis.

Penelitian ini bertujuan untuk mempelajari pengaruh jenis rizobakteri dan waktu awal bakterisasi, yaitu bakterisasi yang dimulai sejak in vitro (planlet) dan bakterisasi saat aklimatisasi (in vivo) untuk menghambat FOC pada tanaman pisang.

\section{BAHAN DAN METODE}

Percobaan dilakukan mulai Januari 2008Februari 2009. Percobaan dimulai dengan persiapan dan perbanyakan propagul pisang secara in vitro sampai mencapai jumlah yang dibutuhkan, perbanyakan isolat rizobakteri dan isolat FOC, dilanjutkan dengan perlakuan bakterisasi planlet secara in vitro di laboratorium Kultur Jaringan dan Laboratorium HPT- Pusat Kajian Buah-buahan Tropika, Institut Pertanian Bogor. Selanjutnya planlet diaklimatisasi, dan pemeliharaan bibit dilakukan di Rumah Kasa, Pusat Kajian Buah-buahan Tropika (sampai bibit berumur 2 bulan). Investasi FOC dilanjutkan di Rumah Kaca BBbiogen, Cimanggu selama 3 bulan.

Bahan uji percobaan menggunakan pisang Rajabulu/AAB (bahan eksplan berupa anakan pisang berasal dari Kebun Perobaan TajurPKBT IPB). Isolat rizobakteri ( $P$. fluorescens ES-32, B. substilis SB-3) berasal dari perakaran tanaman famili Graminae yang sudah teruji karakter fisiologisnya terhadap FOC dan perannya sebagai pemacu pertumbuhan tanaman (Eliza, 2004). Isolat cendawan patogen adalah FOC ras-4 (IPB-057). Isolat rizobakteri dan isolat FOC tersebut diperoleh dari koleksi Dr Widodo, Laboratorium Mikologi TumbuhanDepartemen Proteksi Tanaman IPB.

Percobaan dirancang dengan Rancangan Petak Terbagi. Petak utama adalah jenis rizobakteri ( $P$. fluorescens ES-32, B. substilis SB-3, campuran keduanya dan perlakuan tanpa rizobakteri). Anak petak adalah waktu aplikasi in vitro (2 minggu, 1 minggu sebelum aklimatisasi) dan in vivo (saat aklimatisasi), dengan 3 ulangan. Masing-masing perlakuan terdiri dari 7 polibag.

Persiapan bahan uji diawali dengan melakukan multiplikasi mother plant pisang Rajabulu sampai sejumlah planlet yang dibutuhkan (kriteria planlet sempurna berdaun dan berakar, vigor, ukuran $\pm 5 \mathrm{~cm}$ ). Memastikan kelayakan bahan uji, dilakukan uji ulang daya virulensi isolat dengan melakukan dual-kultur in vitro di media $P D A$ pada cawan petri $(9 \mathrm{~cm})$ antara $F O C$ dengan rizobakteri. Biakan dual kultur diinkubasikan pada suhu kamar selama 7 hari, sampai pertumbuhan miselium cendawan Fusarium pada sisi-sisi tanpa bakteri mencapai petri, dan rizobakteri memperlihatkan aktivitas antifungal dengan menunjukkan halo di antara $F O C$ dan rizobakteri. Uji daya virulensi cendawan patogen FOC terhadap bibit pisang, dilakukan dengan menginfeksi perakaran pisang Rajabulu dengan biakan murni FOC, dan mengamati gejala $F O C$ yang muncul.

Bakterisasi in vitro dilakukan terhadap planlet Rajabulu dengan suspensi rizobakteri sesuai perlakuan ( $P$. fluorescens ES-32, $B$. substilis SB-3, bakteri campuran) dengan kepadatan populasi $10^{9} \mathrm{cfu} \mathrm{ml}^{-1}$ sebanyak $10 \mathrm{ml}$ per botol kultur berisi 10 planlet dan diinkubasikan selama 1-2 minggu (sesuai perlakuan) sebelum dilakukan aklimatisasi. Perlakuan bakterisasi saat aklimatisasi (in vivo), dilakukan dengan mengeluarkan tanaman dari botol kultur, mecuci akar dengan air mengalir untuk menghilangkan media dari perakaran selanjutnya menginokulasikan suspensi rizobakteri dengan kepadatan populasi $10^{9} \mathrm{cfu}$ $\mathrm{ml}^{-1}$ sebanyak $10 \mathrm{ml}$ per botol kultur berisi 10 planlet, dinkubasikan selama 24 jam untuk kemudian dilakukan aklimatisasi. Untuk kontrol perlakuan tanpa bakteri baik in vitro atau in vivo, suspensi rizobakteri diganti dengan air steril. Aklimatisasi tanaman ditempat teduh selama 1 minggu, kemudian dipindahkan ke rumah kaca, setelah 2 bulan bibit siap untuk ditanam pada media yang telah diinvestasi patogen (khlamidospora FOC). 
Persiapan media tanam (tanah dan pupuk kandang dalam polibag masing-masing seberat 5 $\mathrm{kg}$ ) dan infestasi isolat FOC (dalam bentuk klamidospora dengan kepadatan $10^{-3}$ ) dipersiapkan minimal 10 hari sebelum tanam. Pemupukan NPK (10 gr/tanaman) diberikan 2 minggu setelah tanam. Selanjutnya dilakukan pengamatan terhadap gejala penyakit yang ditimbulkan, peubah yang diamati adalah (i) Periode Inkubasi (PI), dihitung dari mulai inokulasi sampai munculnya gejala awal yang ditandai dengan terjadinya penguningan yang paling cepat pada bagian bawah daun pertama atau daun kedua (dengan mengamati gejala eksternal yang biasanya terlihat dari tepi daun menuju ke pangkal atau pelepah daun), (ii) Gejala atau Kejadian Penyakit (Disease Incidence $=\mathrm{DI}$ ), yaitu perhitungan persentase jumlah tanaman yang menunjukkan gejala $F O C$ dilakukan dengan cara mengamati gejala luar (gejala eksternal), yang dilakukan satu bulan setelah inokulasi, pengamatan selanjutnya dilakukan setiap bulan sampai akhir penelitian, perhitungan menggunakan rumus Campbell \& Madden (1990), yaitu:

$$
D I=\frac{n}{N} 100 \%
$$

(DI = Disease Incidence, $\%$ tanaman terserang; $\mathrm{n}=$ jumlah tanaman terserang; $\mathrm{N}=$ jumlah tanaman yang diamati)

(iii) Indeks Keparahan Penyakit (Diesease Severty = DS), diukur pada keparahan gejala layu daun (LSI= Leaf Symptom Index) dan pengukuran keparahan diskolorisasi atau kerusakan jaringan pembuluh pada bonggol (RDI = Rhizome Discoloration Index), berdasarkan hasil pengamatan/skoring dihitung menggunakan rumus (Cachinero et al.2002) :

$$
D S=\frac{\sum_{i=1}^{6}\left(n_{i} v_{i}\right)}{Z N} 100 \%
$$

$(\mathrm{DS}=$ Disease Severity $(\%)(\mathrm{LSI} ; \mathrm{RDI}) ; \mathrm{ni}=$ jumlah batang yang terserang pada setiap katagori ; vi = nilai numerik masing-masing kategori serangan ; $\mathrm{Z}=$ nilai numerik kategori serangan tertinggi dan $\mathrm{N}=$ jumlah batang semu yang diamati)

Pengamatan gejala penyakit berupa tanaman layu yang diawali dengan penguningan mulai dari pinggir atau bagian bawah daun pertama atau ke dua yang kemudian meluas ke bagian tengah. Selanjutnya daun menjadi coklat, mengering pada serangan berat tangkai daun sekeliling batang palsu patah dan mati. Skoring gejala layu yang ditunjukkan oleh gejala serangan tanaman (modifikasi Eep. 1987) (Gambar 1).

Gejala tingkat keparahan penyakit internal nampak pada jaringan pembuluh (xilem) atau batang bila dibelah secara membujur (vertikal) maupun secara horizontal berupa garis-garis berwarna coklat kemerahan sampai kehitaman. Pengukuran diskolorisasi atau kerusakan jaringan pembuluh pada bonggol tiap kultivar pisang dilakukan dengan modifikasi metoda Cordiero (1994), memotong bonggol menjadi 6 bagian secara horizontal, dimulai dari bagian bawah ke atas. Skoring dilakukan pada masing-masing bagian dan selanjutnya hasil dijumlahkan (Gambar 2).

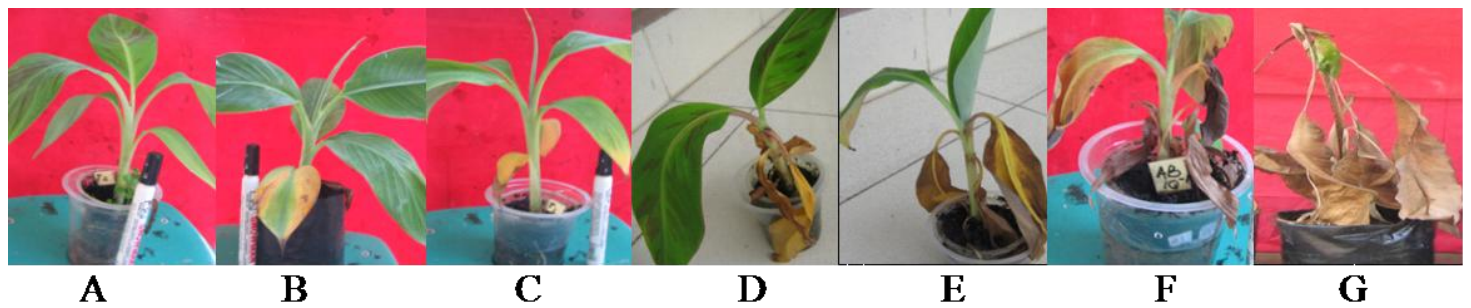

Gambar 1. Skoring gejala Fusarium oxysporum (FOC) pada daun pisang: (A). Skor $0=$ tidak ada gejala bercak daun kuning, tanaman nampak sehat; (B). Skor 1 = ada gejala bercak daun kuning pada 1-2 daun bawah. (C). Skor 2 = gejala daun kuning lebih dari 2 daun ( $\leq 50 \%)$; (D). Skor 3 = gejala daun kuning makin banyak $(>50 \%)$; (E). Skor $4=$ gejala daun kuning makin banyak, tinggal 1 daun hijau; (F). Skor $5=$ semua daun sudah kuning (100\%); (G). Skor $6=$ tanaman mati. 


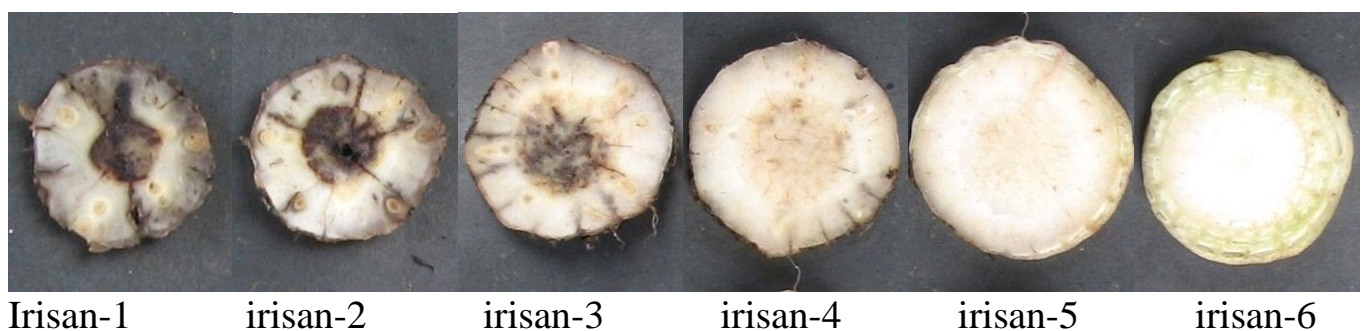

Gambar 2 Diskripsi skoring RDI: Bonggol dibagi menjadi enam irisan, masing-masing irisan di skor (Irisan-1 = skor 5; Irisan-2 = skor 5;Irisan-3 = skor 4;Irisan-4 = skor 2; Irisan-5 = skor 0;

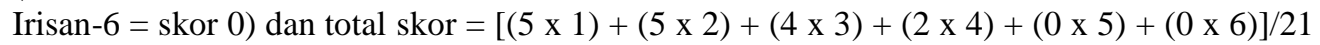
$=1.66$

Nilai skoring (skala diskolorisasi) setiap katagori serangan menggunakan metode Corderio (1994), diskripsi kategori gejala diskolorisasi bonggol ditampilkan pada Gambar 3. Respon terhadap nilai keparahan penyakit baik dilihat dari gejala internal (RD) atau eksternal (LS) dilakukan dengan kategori keparahan sebagai berikut: tanaman sehat bila nilai $\mathrm{DS}=0 \%(\mathrm{SH})$; keparahan sangat ringan jika $0<\mathrm{DS} \leq 10 \%(\mathrm{R})$; keparahan ringan jika
$10<\mathrm{DS} \leq 25 \%$ (R); keparahan sedang jika 25 $<\mathrm{DS} \leq 50 \% \quad$ (S); berat jika $\mathrm{DS}>50 \% \quad$ (B) (modifikasi Purwati, 2007).

Pengamatan gejala internal juga dilakukan terhadap akar tanaman dengan menghitung total akar, akar sehat dan akar sakit. Pelaksanaan dilakukan dengan cara membelah akar, pada akar yang sakit ditandai dengan adanya garis berwarna kecoklatan sampai hitam pada jaringan pembuluh akar (Gambar 4).

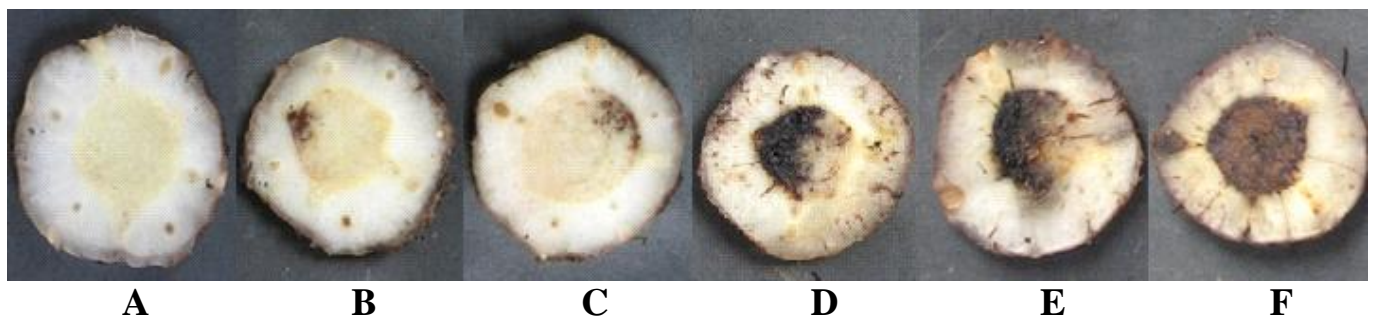

Gambar 3. Skoring diskolorisasi Fusarium oxysporum (FOC) pada bonggol pisang (gejala internal, rhizome discoloration/RD)skor 0-5: (A) Skor $0=$ tidak ada diskolorisasi pada jaringan pembuluh ( $\mathrm{V}=0$ ); (B) Skor $1=$ diskolorisasi $0<\mathrm{V} \leq 10 \%$; (C) Skor $2=$ diskolorisasi $10 \%<$ $\mathrm{V} \leq 33 \%$; (D) Skor $3=$ diskolorisasi $33 \%<\mathrm{V} \leq 66 \%$; (E) Skor $4=$ diskolorisasi $66 \%<\mathrm{V}<$ $100 \%$; (F) Skor $5=$ diskolorisasi $100 \%$

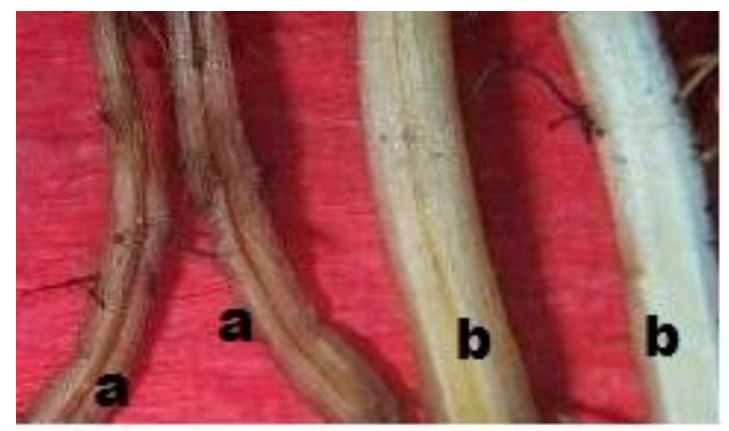

Gambar 4. Gejala diskolorisasi pada jaringan pembuluh akar pisang: pembuluh akar yang sakit (a); jaringan pembuluh akar sehat (b) 


\section{HASIL DAN PEMBAHASAN}

Hasil pengujian dual culture secara in vitro terhadap rizobakteri yang mempunyai aktivitas antifungal terhadap FOC (Gambar 5A), menunjukkan adanya hambatan pertumbuhan dari miselium Fusarium dan terbentuknya halo zona bening di antara pertumbuhan dengan rizobakteri ( $P$. fluorescens ES-32, B. subtilis SB-3). Selain itu dilakukan uji pendahuluan daya virulensi cendawan patogen FOC ras-4 dengan menginvestasikan klamidospora ke perakaran pisang Rajabulu. Setelah masa inkubasi muncul gejala FOC pada 1 sampai 2 daun tertua paling bawah menunjukkan gejala kuning dimulai dari tepi daun (Gambar 5B dan 5C), dengan demikian bahan uji layak digunakan.

Selain itu dilakukan uji pendahuluan daya virulensi cendawan patogen $F O C$ ras -4 dengan menginfestasikan klamidospora ke perakaran pisang cv Rajabulu. Setelah masa inkubasi muncul gejala $F O C$ pada 1 sampai 2 daun tertua paling bawah menunjukkan gejala kuning dimulai dari tepi daun (Gambar 5B dan 5C), dengan demikian bahan uji layak digunakan.

Tabel 1 menunjukkan bahwa semua perlakuan rizobakteri memberikan jumlah akar yang sama banyak, secara statistik tidak berbeda nyata. Dengan demikian perlakuan rizobakteri tidak berpengaruh terhadap jumlah akar.
FOC merupakan patogen tular tanah yang bersifat penghuni akar, sehingga kesempatan masuk ke dalam akar melalui lubang-lubang alami atau luka. Selanjutnya FOC masuk ke dalam bonggol melalui jaringan pembuluh akar tanaman. Gejala yang ditimbulkan oleh FOC pada akar tanaman pisang adalah jaringan pembuluh berwarna kecoklatan (Gambar 4).

Pengaruh perlakuan rizobakteri terhadap kesehatan akar berbeda nyata, ditunjukan oleh jumlah akar sehat dan akar sakit (Tabel 1). Jumlah akar sehat tertinggi dicapai oleh tanaman yang diberi perlakuan campuran dua rizobakteri (17.52), Tanaman yang diberi perlakuan B.subtilis (11.88) tidak berbeda nyata secara statistik dengan tanaman tanpa perlakuan rizobakteri (11.34). Jumlah akar sehat terendah terjadi pada perlakuan $P$. fluorescens (6.22). Jumlah akar sakit terendah dicapai oleh tanaman yang diberi perlakuan rizobakteri campuran $(1,19)$, dan hasil tersebut berbeda nyata. Populasi rizobakteri antagonis secara tidak langsung berperan terhadap penekanan keparahan penyakit. Persaingan zona infeksi dalam hal ruang, nutrisi dan keberadaan rizobakteri pada jaringan akar diduga mampu mendorong pertahanan tanaman terhadap infeksi penyakit. Pertahanan secara langsung dapat melalui mekanisme penghambatan parasitisme, sifat antagonis rizobakteri dapat menyebabkan lisis pada patogen sehingga hifa tak mampu berkembang lebih lanjut (Hallmann, 1997).

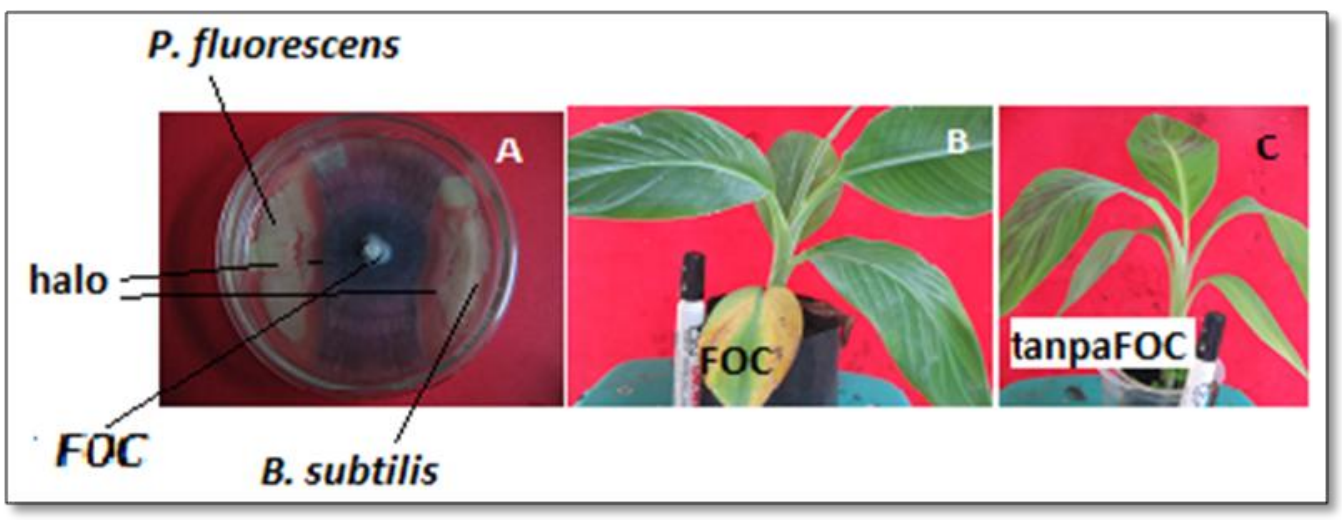

Gambar 5. Pengujian daya virulensi FOC secara in vitro melalui dual kultur antara rizobakteri (Bacillus substilis-SB3 dan P. fluorescens ES-32) dan Fusarium oxysporum f.sp cubense ras-4 (FOC) (A); Pengujian virulensi FOC secara in vivo dengan menginvestasikan klamidispora pada perakaran bibit pisang Rajabulu. Setelah melewati masa inkubasi gejala daun kuning karena $F O C$ nampak pada daun bibit (B) dan bibit pisang Rajabulu tanpa FOC tampak sehat (C) 
Interaksi antara perlakuan macam rizobakteri dan waktu aplikasi pada pisang Rajabulu terhadap parameter gejala penyakit tidak berbeda nyata. Selanjutnya analisis pengaruh mandiri perlakuan waktu aplikasi rizobakteri secara in vitro (1 dan $2 \mathrm{MSbA}$ ) terhadap Periode Inkubasi, Kejadian Penyakit dan Keparahan Penyakit ( $L S I$ dan $R D I$ ) pada pisang Rajabulu juga tidak berbeda nyata dengan perlakuan bakterisasi saat aklimatisasi
(0 MSbA) (Tabel 2 dan Tabel 3). Berarti introduksi rizobakteri bisa dilakukan lebih awal yaitu saat planlet masih kondisi in vitro (1-2 MSbA), pada saat planlet sudah berakar. Waktu tersebut menciptakan kondisi bakteri dapat berinteraksi lebih lama dengan tanaman, bakteri mendapat kesempatan berproliferasi di akar sebelum diaklimatisasi dan lebih ekonomis distribusi planlet/bibit.

Tabel 1 Pengaruh rizobakteri terhadap jumlah akar serta kesehatan akar

\begin{tabular}{lccc}
\hline Rizobakteri & Jumlah Akar & Akar Sehat & Akar Sakit \\
\hline P. fluorecens & $16.25 \mathrm{a}$ & $6.22 \mathrm{c}$ & $10.03 \mathrm{a}$ \\
B. subtilis & $16.03 \mathrm{a}$ & $11.88 \mathrm{~b}$ & $4.15 \mathrm{ab}$ \\
Campuran & $18.71 \mathrm{a}$ & $17.52 \mathrm{a}$ & $1.19 \mathrm{c}$ \\
Tanpa bakteri & $17.84 \mathrm{a}$ & $11.34 \mathrm{~b}$ & $6.50 \mathrm{ab}$ \\
\hline
\end{tabular}

Keterangan: Angka-angka yang diikuti oleh huruf yang sama pada kolom yang sama tidak berbeda nyata pada uji Duncan pada taraf $\alpha=5 \%$.

Tabel 2. Pengaruh waktu aplikasi penggunaan rizobakteri terhadap periode inkubasi (PI), kejadian penyakit (DI) pada pisang Rajabulu

\begin{tabular}{lccccccc}
\hline \multirow{2}{*}{ Rizobakteri } & \multirow{2}{*}{ P.Inkubasi } & \multicolumn{6}{c}{ Minggu Setelah Tanam } \\
\cline { 3 - 7 } & (hari) & 9 & 10 & 11 & 12 & 13 & 16 \\
\hline & & & $---------K e j a d i a n$ & Penyakit (\%)--------- \\
$0 \mathrm{MSbA}$ & $74.76 \mathrm{a}$ & $34.52 \mathrm{a}$ & $53.57 \mathrm{a}$ & $72.62 \mathrm{a}$ & $90.48 \mathrm{a}$ & $92.86 \mathrm{a}$ & $77.38 \mathrm{a}$ \\
$1 \mathrm{MSbA}$ & $73.27 \mathrm{a}$ & $41.67 \mathrm{a}$ & $57.14 \mathrm{a}$ & $76.19 \mathrm{a}$ & $86.91 \mathrm{a}$ & $95.24 \mathrm{a}$ & $78.57 \mathrm{a}$ \\
$2 \mathrm{MSbA}$ & $73.13 \mathrm{a}$ & $33.33 \mathrm{a}$ & $57.14 \mathrm{a}$ & $75.00 \mathrm{a}$ & $89.29 \mathrm{a}$ & $97.62 \mathrm{a}$ & $83.33 \mathrm{a}$
\end{tabular}

Keterangan: Angka-angka yang diikuti oleh huruf yang sama pada kolom yang sama tidak berbeda nyata pada uji Duncan pada taraf $\alpha=5 \%$.

Tabel 3. Pengaruh waktu aplikasi penggunaan rizobakteri terhadap keparahan penyakit (LS dan RD) pada pisang Rajabulu

\begin{tabular}{|c|c|c|c|c|c|c|c|}
\hline \multirow[b]{2}{*}{ Waktu aplikasi } & \multirow{2}{*}{$\begin{array}{c}\text { Keparahan } \\
\text { bonggol } \\
(\mathrm{RD})(\%)\end{array}$} & \multicolumn{6}{|c|}{ Minggu Setelah Tanam } \\
\hline & & 9 & 10 & 11 & 12 & 13 & 16 \\
\hline & $16 \mathrm{MST}$ & \multicolumn{6}{|c|}{---------Keparahan Penyakit (LS)(\%)--------- } \\
\hline $0 \mathrm{MSbA}$ & $39.92 \mathrm{a}$ & $17.26 \mathrm{a}$ & $23.41 \mathrm{a}$ & $29.56 \mathrm{a}$ & $37.30 \mathrm{a}$ & $42.66 \mathrm{a}$ & $41.44 \mathrm{a}$ \\
\hline $1 \mathrm{MSbA}$ & $34.63 \mathrm{a}$ & $19.05 \mathrm{a}$ & $24.01 \mathrm{a}$ & $30.16 \mathrm{a}$ & $38.49 \mathrm{a}$ & $41.87 \mathrm{a}$ & $36.18 \mathrm{a}$ \\
\hline $2 \mathrm{MSbA}$ & $36.30 \mathrm{a}$ & $16.47 \mathrm{a}$ & $22.82 \mathrm{a}$ & $31.75 \mathrm{a}$ & $37.30 \mathrm{a}$ & $41.27 \mathrm{a}$ & $38.62 \mathrm{a}$ \\
\hline
\end{tabular}

Keterangan : Angka-angka yang diikuti oleh huruf yang sama pada kolom yang sama tidak berbeda nyata pada uji Duncan pada taraf $\alpha=5 \%$. Respon keparahan penyakit sehat ( $\mathrm{ds}=0 \%)$, Sangat Ringan $(0<\mathrm{ds} \leq 10 \%)$, Ringan $(10<\mathrm{ds} \leq 25 \%)$ sedang $(25<\mathrm{ds} \leq 50 \%)$, berat $(\mathrm{ds}>50)$ 
Pengaruh faktor mandiri perlakuan rizobakteri terhadap periode inkubasi antar perlakuan tidak menunjukkan beda nyata. Kejadian penyakit diukur berdasar persentase jumlah tanaman yang menunjukkan gejala $F O C$ (gejala eksternal) tanpa memperhitungkan kategori tingkat serangan, sehingga untuk menjelaskan sampai seberapa jauh tingkat kerusakan perlu di amati keparahan penyakit internal dan eksternal (Tabel 4).

Tabel 5 menunjukkan asosiasi rizobakteri campuran dengan tanaman pisang Rajabulu pada minggu ke 16 menunjukkan pengaruh yang nyata terhadap penurunan gejala keparahan penyakit (LS) sampai katagori ringan (18.61\%) dibandingkan dengan aplikasi rizobakteri secara tunggal (Bacillus subtilis SB3 atau Pseudomonas fluorecens ES32) dan tanpa rizobakteri (berkatagori sedang).

Pengamatan terhadap parameter keparahan penyakit pada bonggol, rizobakteri campuran juga menurunkan keparahan sampai katagori ringan (18.98\%) dibandingkan tanpa rizobakteri yaitu katagori berat $(55.51 \%)$ dan rizobakteri tunggal (Bacillus subtilis SB3 atau Pseudomonas fluorecens ES32) menunjukkan kategori sedang (34.57\% dan 38.75\%)(Tabel.5). Mengingat FOC lebih dikenal sebagai cendawan penghuni akar, setelah masuk melewati lubang alami atau luka di akar selanjutnya akan masuk ke bonggol, dari sini patogen akan berkembang dengan cepat sampai ke jaringan pembuluh (Wardlaw, 1972). Jadi penentu yang mampu memberi gambaran seberapa jauh tingkat keparahan penyakit yang disebabkan oleh FOC, adalah gejala yang teramati di akar dan di bonggol. Berarti asosiasi kedua jenis rizobakteri tersebut (Bacillus subtilis SB3 dan Pseudomonas fluorecens ES32) secara bersama-sama menekan keparahan penyakit layu Fusarium.

Penekanan keparahan penyakit oleh kedua populasi antagonis tersebut secara tidak langsung diduga dapat melalui persaingan dengan patogen pada zona infeksi dalam hal ruang dan nutrisi. Kompetisi umumnya terjadi karena keterbatasan salah satu faktor yang dibutuhkan untuk pertumbuhan dan perkembangan agen atau patogen, seperti unsur esensial tertentu. Atau penekanan penyakit melalui mekanisme antibiosis, senyawa antibiotik menghambat pertumbuhan patogen melalui kontak langsung antara agens dengan patogen. $P$. fluorescens memproduksi senyawa siderofor yang mampu mengkelat $\mathrm{Fe}$, sehingga menghambat pertumbuhan patogen. Agens biokontrol yang digunakan mampu memparasit patogen dengan cara mensekresikan enzim ekstraseluler (kitinase, protease, selulase) yang dapat melisis atau mendegradasi dinding sel patogen sehingga perkembangan patogen menjadi terhambat. Di samping itu beberapa agen biokontrol mampu menghasilkan hidrogen sianida $(\mathrm{HCN})$ yang bersifat toksik terhadap sejumlah patogen tanaman (Wei et al., 1996; Baker dan Cook, 1974; Silva et al., 2004, Barka et al., 2002 dan Frommel et al., 1991).

Tabel 4. Pengaruh rizobakteri terhadap periode inkubasi (PI) kejadian penyakit (DI) pada pisang Rajabulu

\begin{tabular}{lccccccc}
\hline \multirow{2}{*}{ Rizobakteri } & \multirow{2}{*}{ P.Inkubasi } & \multicolumn{7}{c}{ Minggu Setelah Tanam } \\
\cline { 3 - 7 } & & 9 & 10 & 11 & 12 & 13 & 16 \\
\hline P. fluorescens & $71.67 \mathrm{a}$ & $47.62 \mathrm{a}$ & $66.67 \mathrm{a}$ & $77.78 \mathrm{a}$ & $88.89 \mathrm{a}$ & $96.83 \mathrm{a}$ & $77.78 \mathrm{ab}$ \\
B. subtiliss & $68.81 \mathrm{a}$ & $49.21 \mathrm{a}$ & $82.54 \mathrm{a}$ & $87.30 \mathrm{a}$ & $93.65 \mathrm{a}$ & $98.41 \mathrm{a}$ & $80.95 \mathrm{ab}$ \\
Campuran & $74.65 \mathrm{a}$ & $31.75 \mathrm{a}$ & $42.86 \mathrm{a}$ & $71.43 \mathrm{a}$ & $88.89 \mathrm{a}$ & $95.24 \mathrm{a}$ & $87.30 \mathrm{a}$ \\
Tanpa perlakuan & $79.76 \mathrm{a}$ & $17.46 \mathrm{a}$ & $31.75 \mathrm{a}$ & $61.90 \mathrm{a}$ & $84.13 \mathrm{a}$ & $90.48 \mathrm{a}$ & $73.02 \mathrm{~b}$
\end{tabular}

Keterangan: Angka-angka yang diikuti oleh huruf yang sama pada kolom yang sama tidak berbeda nyata pada uji Duncan pada taraf $\alpha=5 \%$. 
J. Hort. Indonesia 2 (1):34-42. April 2011.

Tabel 5. Pengaruh rizobakteri terhadap keparahan penyakit (LS dan RD) pada pisang Rajabulu

\begin{tabular}{|c|c|c|c|c|c|c|c|}
\hline \multirow[b]{2}{*}{ Rizobakteri } & \multirow{2}{*}{$\begin{array}{c}\text { Keparahan } \\
\text { bonggol } \\
(\mathrm{RD})(\%)\end{array}$} & \multicolumn{6}{|c|}{ Minggu Setelah Tanam } \\
\hline & & 9 & 10 & 11 & 12 & 13 & 16 \\
\hline & $16 \mathrm{MST}$ & \multicolumn{6}{|c|}{----------Keparahan Penyakit (LS)(\%)--------- } \\
\hline P. fluorescens & $38.75 \mathrm{~b}$ & $22.49 \mathrm{a}$ & $28.31 \mathrm{a}$ & $35.45 \mathrm{a}$ & $40.74 \mathrm{ab}$ & $43.12 \mathrm{ab}$ & $46.34 \mathrm{a}$ \\
\hline B. subtiliss & $34.57 \mathrm{bc}$ & $20.90 \mathrm{a}$ & $30.16 \mathrm{a}$ & $37.30 \mathrm{a}$ & $43.92 \mathrm{a}$ & $46.83 \mathrm{a}$ & $43.56 \mathrm{a}$ \\
\hline Campuran & $18.98 \mathrm{c}$ & $13.76 \mathrm{a}$ & $17.99 \mathrm{a}$ & $25.13 \mathrm{a}$ & $32.01 \mathrm{c}$ & $37.83 \mathrm{~b}$ & $18.61 \mathrm{~b}$ \\
\hline Tanpa perlakuan & $55.51 \mathrm{a}$ & $13.23 \mathrm{a}$ & $17.20 \mathrm{a}$ & $24.07 \mathrm{a}$ & $34.13 \mathrm{bc}$ & $39.95 \mathrm{ab}$ & $46.47 \mathrm{a}$ \\
\hline
\end{tabular}

Keterangan : Angka-angka yang diikuti oleh huruf yang sama pada kolom yang sama tidak berbeda nyata pada uji Duncan pada taraf $\alpha=5 \%$. Respon keparahan penyakit sehat (ds=0\%), Sangat Ringan $(0<\mathrm{ds} \leq 10 \%)$, Ringan $(10<\mathrm{ds} \leq 25 \%)$, sedang $(25<\mathrm{ds} \leq 50 \%)$, berat $(\mathrm{ds}>50)$

\section{KESIMPULAN}

Campuran dua rizobakteri (Bacillus subtilis SB3 dan Pseudomonas fluorecens ES32) yang diaplikasi saat in vitro pada planlet yang sudah berakar (1-2 minggu sebelum aklimatisasi) merupakan perlakuan terbaik, mampu menurunkan keparahan penyakit (Disease severity) akibat cendawan Fusarium oxysporum f.sp cubense sampai kategori ringan.

\section{UCAPAN TERIMAKASIH}

Penulis mengucapkan terimakasih atas sebagian biaya penelitian kepada RUSNAS Pengembangan Buah-buahan Unggulan Indonesia melalui Pusat Kajian Buah-buahan Tropika IPB; Sekretariat Badan Litbang Pertanian melalui KKP3T; Ford Foundation melalui Indonesian Scholar Dissertation Award.

\section{DAFTAR PUSTAKA}

Baker, K.F., R.J. Cook, 1974 . Biological control of plant pathogens.: W.H Freeman and company. San Fransisco $433 p$.

Barka, A.B., S. Gognies, J. Nowal, J.C. Audran, Belarbi A. 2002. Inhibitory effect of endophyte bacteria on Botrytis cinerea and its influence to promote the grapevine growth. Biological Control 24 :135-142.
Cachinero, J.M., A. Hervas, R.M. JimenezDiaz, M. Tena. 2002. Plant defence reactions againts Fusarium wilt in chickpea induced by incopatible race 0 of Fusarium oxysporum f.sp ciceres and non-host isolates of oxysporum. Plant Pathol 51:765-776.

Campbell, C.L., J.W. Madden. 1990. Introduction to Plant Diseases Epidemiology. New York: JW \& Sons.

Cordiero, M. 1994. Scale for Rating The Internal Corm Symptoms Caused by Fusarium wilt. Di dalam: Dr Jones, editor. The Improvement and Testing of Musa: A Global Partnership. Proceeding of thr Global Conference of International Musa Testeing Program held at FHIA, Honduras. INIBAB.p 284.

[Ditlinhorti] Direktorat Perlindungan Tanaman Hortikultura. 2005. Luas serangan organisme penganggu utama tanaman pisang.

http//www.deptan.go.id/ditlinhorti

Epp, D. 1987. Somaclonal variation in banana: a case study with Fusarium wilt. Di dalam: G.J. Persley, E.A. De Lange (ed). Banan and Plantain Breeding Strategis. Canbera: ACIAR Publ, 140-150.

Frommel, M.I., J. Nowak, Lazarovita. 1991. Growth Enhancement and Developmental Modifications of in Vitro Grown Potato (Solanum tuberosum ssp. Tuberosum) as Affected by a 
Nonfluorescent Pseudomonas sp. Plant Physiol. 96: 928-936.

Gowen, S. 1995. Bananas and Plantains. Chapman \&Hall. London.

Hallman, J, A. Quadt-Hallman, W.F. Mahafee, J.W. Kloepper. 1997. Bacterial endophytes in agricultural crops. Can J Mikrobiol 43: 895-914.

Kasutjianingati, R. Poerwanto, Widodo, N. Khumaida, D. Efendi. 2010. Pengaruh Bakteri Endofit terhadap Multiplikasi Tunas Pisang Rajabulu secara In-vitro. Agriplus. Vol 20 (03 September):227232.

Nowak, J. 1988. Benefits of in vitro" biotization" of plant tissue cultures with microbial inoculants. In vitro Cell. Dev. Biol. Plant 34: 122-130.

Purwati, R.D. 2007. Variation Somaklonal dan Seleksi In Vitro Abaka (Musa textillis Nee) untuk Ketahanan Terhadap Layu Fusarium. [Disertasi]. Bogor: Institut Pertanian Bogor.

Ploetz, R.C. 1998. Fusarium Wilt (Panama Diesease). In Ploetz RC. Editor. Compendium of tropical fruit disease. Minesota: APS pr. p: 10-11.
Ploetz, R.C, K.G. Pegg. 2000. Diesease of banana, abaca and enset : Fungal disease of the root, corm and pseudostem. . In Jones, D.R. , 2000. Introduction to banana, abaca and enset . CAB Production. London. p 143-159.

Silva, H.S.A., R.S Romeiro, D. Macagnan, B.A Halfeid-Vieira, M.C.B. Pereira, Mounteer. 2004. Rhizobacterial inductions of systemic resistance in tomato plants non-specific protection and increase in enzyme activities. Biological Control 29: 288-295.

Wardlaw, C.W. 1972. Banana Disease: Including Plantains and Abaca 2 nd Longmans, London.

Wei, G., J.W. Kloepper, S. Tuzun. 1996 Induced Systetemic Resistance to Cucumber Diseases and Increased Plant Crowth by Plant Growth-Promoting Rhizobacteria Under Field Conditions. Biological Control vol 86 (2) : 221-231.

Zhang, Y. 2004. Biocontrol of sclerotia stem rot of canola by bacterial antagonists and study of biocontrol mechanisms involved (Thesis). Winnipeg. Canada: Departemen of Plant Science. Universitas of Manitoba. http://mspace.lib.umanitoba.ca/bitstream/ 1993/121/1/Yilan's+thesis-MSpace.pdf. 